\title{
Implementasi Teknologi Informasi dan Balance Scorecard Mahasiswa Fakultas Ekonomi dan Ilmu Sosial UIN Suska Riau (Survai Terhadap Mahasiswa Semester VI Prodi Manajemen S1)
}

\author{
Irien Violinda Anggriani \\ UIN Sultan Syarif Kasim Riau, Pekanbaru, Indonesia
}

\begin{abstract}
ABSTRAK: Kemajuan dalam penerapan teknologi informasi (TI) dalam berbagai bidang kehidupan menjadikan jarak (geografis) menjadi tidak penting bagi mereka yang memiliki akses terhadap TI. Siapapun yang terhubung dengan TI dapat mengakses informasi yang berada dimanapun dan berkomunikasi dengan siapapun, dengan menggunakan internet. TI mendorong perubahan mendasar dalam kehidupan sehari-hari manusia, termasuk dalam kegiatan belajar dan mengajar (PBM) diperguruan tinggi. Sebagai salah satu penunjang (PBM), implementasi teknologi informasi Mahasiswa dan Dosen Pengampu mengadakan kunjungan industri ke PT. Indofood CBP Sukses Makmur, Tbk, Cabang Pekanbaru, guna mengamati, memahami dan mengetahui secara langsung proses produksi yang memanfaatkan teknologi informasi itu sendiri. Balance Scoredcard (BSC) adalah suatu mekanisme sistem manajemen yang mampu menerjemahkan visi dan strategi organisasi ke dalam tindakan nyata dilapangan dan memberikan kontribusi dalam peningkatan mutu lulusan serta kinerja perguruan tinggi melalui empat perspektif yaitu keuangan, pelanggan, proses bisnis internal serta pembelajaran dan pertumbuhan.
\end{abstract}

Kata Kunci: Teknologi Informasi, Balanced Scorecard

\begin{abstract}
Progress in the application of information technology (IT) made in various areas of the geographical distance was not important to them who had access to it.Anyone connected with IT can access information that is everywhere and communicate with anyone, using the internet. IT encourages fundamental changes in daily life, including in their learning. As one of supporting in a college, implementation information technology the students and teachers visit an industry to learn to PT.Indofood CBP Sukses Makmur,Tbk, Branch of Pekanbaru. to observe, understand and directly know the production process that use information technology. Balance Scoredcard (BSC) is management mechanism system to translate the vision and strategy organization into real action field and contributed in the improvement of the quality of graduates and performance college through four, the financial perspective, customers of business process and learning and. internal growth.
\end{abstract}

Keywords: Information Technology, Balanced Scorecard

Email Address: violindairien@yahoo.com

\section{Pendahuluan}

Dengan semakin berkembangnya teknologi informasi saat ini, dimana segala kegiatan dalam kehidupan sehari-hari akan berbasis komputer. Dalam suatu instansi penggunaan komputer merupakan bahan kebutuhan dalam menciptakan dan memperoleh serta memproses suatu sistem informasi yang setiap saat selalu berkembang. Oleh karena itu setiap orang harus mampu berupaya mengikuti arus informasi yang berkembang didunia teknologi ini. Baik instansi pemerintah, perusahaan maupun institusi pendidikan seperti perguruan tinggi manapun saat ini pastilah menggunakan Sistem Informasi Manajemen dimana merupakan sebuah sistem manusia atau mesin 
yang terpadu (integrated), untuk menyajikan informasi guna mendukung fungsi operasi, manajemen dan pengambilan keputusan.

Tidak dapat disangkal bahwa salah satu penyebab utama terjadinya era globalisasi yang datangnya lebih cepat yaitu karena perkembangan pesat teknologi informasi. Kemajuan teknologi digital yang dipadu dengan telekomunikasi telah membawa komputer memasuki masa-masa revolusinya. Kegunaan komputer di perusahaan tidak hanya untuk meningkatkan efisiensi, namun lebih jauh untuk mendukung terjadinya proses kerja yang lebih efektif. Tidak seperti halnya pada era komputerisasi dimana komputer hanya menjadi hak milik Divisi EDP (Electronic Data Processing) perusahaan, namun saat ini setiap individu diorganisasi dapat memanfaatkan kecanggihan komputer, seperti untuk mengolah database, spreadsheet, maupun data processing (end-user computing). Tidak ada yang dapat menahan lajunya perkembangan teknologi informasi.

Kemajuan dalam penerapan teknologi informasi (TI) dalam berbagai bidang kehidupan menjadikan konsep jarak geografis menjadi tidak penting bagi mereka yang memiliki akses terhadap TI. Siapapun yang terhubung dengan TI dapat mengakses informasi yang berada di manapun dan berkomunikasi dengan siapapun di manapun dia berada dengan menggunakan internet. TI mendorong perubahan mendasar dalam kehidupan sehari-hari manusia, termasuk dalam kegiatan belajar dan mengajar diperguruan tinggi.

Teknologi informasi pada dasarnya terdiri atas 3 komponen utama, teknologi komputer (hardware dan software), teknologi content (database dan multimedia), dan teknologi komunikasi (network dan internet). Perkembangan 3 komponen utama TI sangatlah cepat dan implementasinya sudah meliputi hampir semua bidang kehidupan dan kegiatan masyarakat dunia. Saat ini TI menjadi salah satu infrastruktur bisnis, artinya kehadiran TI sangatlah diperlukan untuk terjadinya kegiatan bisnis, membuat lebih efisien, produktif, dan memberikan banyak kesempatan untuk meningkatkan keunggulan bersaing dalam bisnis. TI tidak hanya dipakai untuk kegiatan pendukung operasional dan manajemen saja, tetapi juga sudah menjadi produk bisnis itu sendiri, produk-produk perbankan yang berbasis sebagai contoh TI: Automatic Teller Machine (ATM), mobile banking, internet banking. Di sisi lain, pengelolaan perguruan tinggi pada dasarnya mengelola 3 aspek utama, yaitu mengelola Process, Content, dan Resources.

Pengelolaan Process dapat dikelompokkan dalam 2 bagian besar, yaitu proses inti yaitu proses untuk menjalankan fungsi Akademik di Perguruan Tinggi, dan proses penunjang (proses terkait dengan fungsi bisnis, seperti keuangan, sdm, dan pemasaran). Pengelolaan Content di perguruan tinggi merupakan aktifitas yang sangat penting, karena di dalamnya terdiri atas mengelola isi pembelajaran, penelitian, dan pengembangan ilmu lainnya. Sedangkan Pengelolaan Resources adalah untuk mengelola semua calon sumberdaya yang dimiliki perguruan tinggi, dalam hal ini adalah mahasiswa. Ketiga aspek utama tersebut Process, Content dan Resources saling terkait dan saling berpengaruh pada budaya organisasi perguruan tinggi. Sejalan dengan proses tersebut perlu pelaksanaan dan penerapan Fungsi-fungsi Manajemen yang walaupun berbeda-beda pada setiap institusi pendidikan, namun pada hakekatnya tetap tidak terlepas dari fungsi-fungsi Planing, Organizing, Actuating dan Controlling, dijelaskan melalui Gambar 1 menunjukkan komponen-komponen pelaksanaan fungsi-fungsi manajemen. 


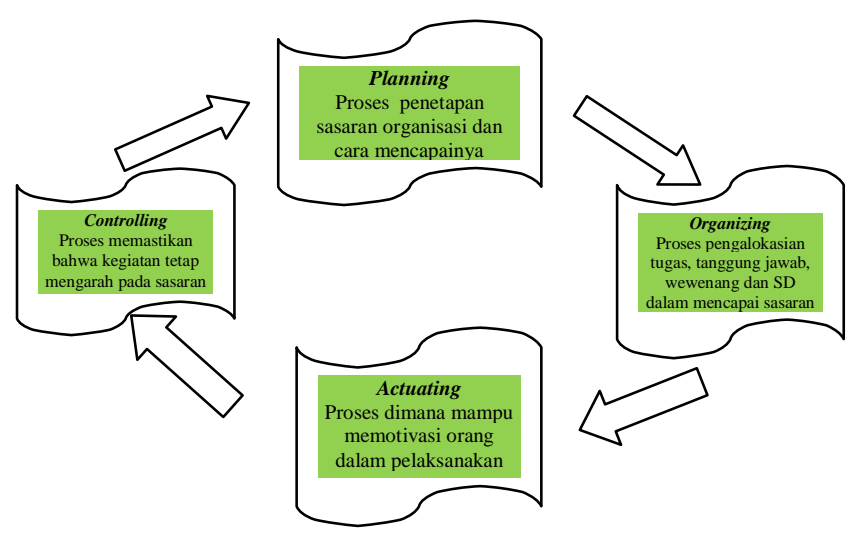

Sumber: Diadaptasi dari Buku Pengantar Manajemen (Sule: 2006)

\section{Gambar 1: Fungsi Manajemen}

Manajeman dalam kaitannya dengan implementasi TI juga dapat dihubungkan dengan Balanced Scorecard yakni suatu metode yang dikembangkan Kaplan dan Norton (2000) untuk mengukur setiap aktivitas yang dilakukan oleh suatu perusahaan dalam rangka merealisasikan tujuan perusahaan tersebut. Balanced Scorecard semula merupakan aktivitas tersendiri yang terkait dengan penentuan sasaran, tetapi kemudian diintegrasikan dengan sistem manajemen strategis. Balanced Scorecard bahkan dikembangkan lebih lanjut sebagai sarana untuk berkomunkasi dari berbagai unit dalam suatu organisasi. Balanced Scorecard juga dikembangkan sebagai alat bagi organisasi untuk berfokus pada strategi.

Strategi merupakan arahan dan ruang lingkup dari perusahaan dalam jangka panjang yang akan memberikan keuntungan bagi perusahaan atau instansi serta perguruan tinggi melalui penggunaan sumber daya yang ada dalam lingkungan yang mendukung untuk memenuhi kebutuhan pasar dan memenuhi harapan dari para stakeholder. Ada dua kemungkinan yang dapat dilakukan, pertama proses bisnis perlu dilakukan modifikasi agar sesuai dengan TI yang digunakan kedua yaitu dengan melakukan penyesuaian atau kustomisasi terhadap TI. Peranaan TI dalam organisasi ini juga akan mempengaruhi penyelarasan yang terjadi dalam perguruan tinggi.

Berbagai upaya yang akan dan telah dilakukan bagi peningkatan mutu pendidikan yaitu dengan mengikuti berbagai pelatihan dan peningkatan mutu (kualitas) serta kompetensi mahasiswa yang berawal dari pemilihan konsentrasi, sehingga mahasiswa lebih terarah serta memiliki keahalian khusus yang dapat diberdayakan kemampuan dan keahliannya setelah selesai kuliah. Begitu pula dengan pengadaan buku dan peralatan penunjang perkuliahan, perbaikan sarana dan prasarana pendidikan, dan meningkatkan mutu manajemen kampus. Sebagai informasi dipaparkan jumlah mahasiswa Semester VI yang sudah berada (duduk) dalam kelas Konsentrasi.

\section{Tabel 1: Jumlah Mahasiswa Semester VI Konsentrasi Prodi Manajajemen Tahun Akademik 2016-2017}

\begin{tabular}{|c|c|c|c|}
\hline Kelas & $\begin{array}{c}\text { Konsentra } \\
\text { si Mgt. } \\
\text { Keuangan }\end{array}$ & $\begin{array}{c}\text { Konsentra } \\
\text { si Mgt. } \\
\text { Pemasa } \\
\text { ran }\end{array}$ & $\begin{array}{c}\text { Konsentra } \\
\text { si Mgt. } \\
\text { SDM }\end{array}$ \\
\hline A & 30 & 45 & 46 \\
\hline B & 30 & 45 & 45 \\
\hline C & 26 & 45 & 45 \\
\hline D & \multicolumn{3}{|c|}{447} \\
\hline Total & \multicolumn{3}{|c|}{} \\
\hline
\end{tabular}

Sumber: Prodi Manajemen, 2017

Dari data tabel 1.1 terlihat jumlah mahasiswa konsentrasi, melalui pemanfaatan teknologi informasi diharapkan berguna bagi pengembangan kemampuan dibidang tersebut yang mana dapat dioptimalkan penggunaannya dalam bidang akademik, baik itu untuk kemudahan akses informasi, pembelajaran dan proses administrasi (surat-menyurat). Penelitian ini mengambil ruang lingkup di Fakultas Ekonomi dan Ilmu Sosial UIN Suska Riau sebagai survai dimana bertujuan untuk melihat, memahami, menganalisis, penggunaan teknologi informasi sehingga 
dapat dimanfaatkan seoptimal mungkin oleh mahasiswa dan melalui empat perspektif keuangan, pelanggan, proses bisnis internal, pertumbuhan dan pembelajaran dalam pendekatan Balance Scorecard sebagai upaya mengimplementasikan Performance Management System (PMS) pada Fekonsos UIN Suska Riau, sehingga tujuan Universitas Islam Negeri Sultan Syarif Kasim Riau secara umum sesuai misi dan visi 2023 tercapai. Dari paparan yang dikemukakan maka penelitian ini akan menganalisis bagaimana peran penggunaan TI dan bagaimana implementasi TI melalui pendekatan Balancescorecard saat ini, dilihat dari aspek keuangan, pelanggan, proses bisnis internal, pertumbuhan dan pembelajaran Mahasiswa Semester VI Prodi Manajemen S1 Fakultas Ekonomi dan Ilmu Sosial UIN Suska Riau?

\section{Landasan Teori}

Seperti yang kita ketahui Peran TI di perguruan tinggi tidak hanya digunakan untuk mengelola kegiatan penunjang (administrasi) namun sudah banyak digunakan untuk kegiatan inti (pembelajaran dan penelitian). Implementasi e-learning adalah salah satu contoh penggunaan TI dalam proses pembelajaran di perguruan tinggi. Penggunaan TI juga untuk mengelola pengetahuan (knowledge management) yang berkembang di perguruan tinggi, baik yang bersifat tacit knowledge maupun explicit knwoledge. Perkembangan penggunaan TI di perguruan tinggi tidak hanya menjadi alat pendukung yang sudah menjadi kagitan startegis dan tidak hanya kegiatan pengelolaan yang bersifat proses, namun menuju pengelolaan yang bersifat konten. Seperti Gambar 2 yang diadaptasi dari penelitian Harjanto Prabowo (2007) menunjukkan peran TI di perguruan tinggi.

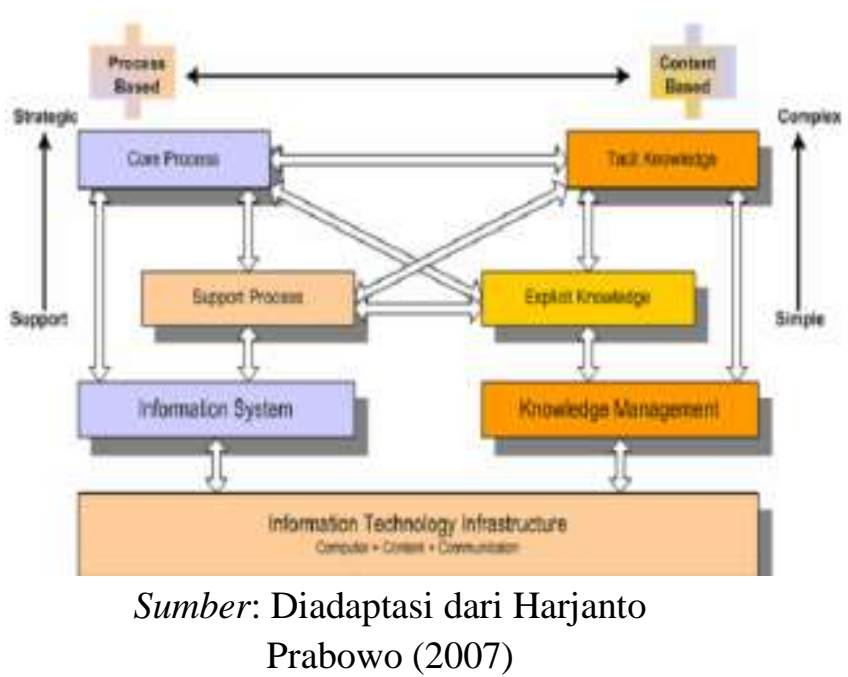

Gambar 2: Peran TI di Perguruan Tinggi

Melihat perkembangan peran TI di perguruan tinggi yang semakin meningkat, haruslah diikuti dengan menata organisasi pengelola TI di perguruan tinggi. Keberhasilan implementasi TI di perguruan tinggi selain mengelola aspek teknis juga mengelola aset yang mahal, serta menjadi salah satu pendorong perubahan budaya organisasi perguruan tinggi serta fungsi-fungsi yang dikelola organisasi TI di perguruan tinggi.

Konsep Balanced Scorecard adalah pendekatan terhadap strategi manajemen yang dikembangkan oleh Robert S. Kaplan dan David Norton pada awal tahun 1990. BSC berasal dari dua kata yaitu balanced (berimbang) dan scorecard (kartu skor). Balanced (berimbang) berarti adanya keseimbangan antara performance (kinerja) keuangan dan non-keuangan, performance jangka pendek dan performance jangka panjang, antara performance yang bersifat internal dan performance yang bersifat eksternal. Sedangkan Scorecard (kartu skor) yaitu kartu yang digunakan untuk mencatat skor performance seseorang.

BSC adalah suatu mekanisme sistem manajemen yang mampu menerjemahkan visi dan strategi organisasi ke dalam tindakan nyata di lapangan. BSC adalah salah satu alat manajemen yang telah terbukti telah 
membantu banyak organisasi mengimplementasikan strategi bisnisnya yang kemudian digunakan untuk mengukur kinerja organisasi keseluruhan, serta membagi kedalam empat perspektif. Empat perspektif tersebut yaitu keuangan, pelanggan, proses bisnis internal serta pembelajaran dan pertumbuhan.

Dalam penelitian mengadaptasi kajian dalam perspektif Islam yang berkaitan dengan pemanfaatan ilmu pengetahuan khususnya TI dan empat Perspektif Balancescorecard, baik yang bersumber dari Al Quran dan Hadits, antara lain.

Dalam sebuah hadis tersebut bahwa Nabi bersabda:

أدبنى ربى فأحسن تأديبى

"Tuhanku telah mendidikku, maka menjadi baiklah pendidikanku”.

Dalam penggalan hadis ini, maka nyatalah bahwa Allah SWT adalah Pendidik Agung bagi para Nabi dan seluruh alam semesta. Dja' far Siddik mengatakan, "Dialah Muaddib Agung, dan Dia pulalah Murabbi Agung yang telah mendidik para Nabi dan Rasul-Nya.Dia juga Mu'allim Agung yang telah membelajarkan Adam AS, nenek moyang umat manusia tentang segala sesuatu. Berdasarkan penjelasan di atas, maka Allah pulalah sesungguhnya pendidik agung manusia. Dengan demikian, pengetahuan tentang alam (ayat-ayat kauniyah) yang juga menjadi objek pengetahuan mengantarkan manusia kepada puncak pencarian ilmu yaitu Allah Swt (ma'rifatullah). Dalam surat anNahl 16 ayat 43 disebutkan yang artinya adalah Dan Kami tidak mengutus sebelum engkau (Muhammad), melainkan orang lakilaki yang Kami beri wahyu kepada mereka; maka bertanyalah kepada orang yang mempunyai pengetahuan jika kamu tidak mengetahui memberikan pendidikan kepada anak secara bebas dan alamiah. Pendapat ini dikemukakannya karena ia menekankan tujuan pendidikan untuk membentuk manusia bebas dan merdeka dari tekanan maupun ikatan serta tidak untuk tujuan tertentu, apakah itu menjadikan peserta didik menjadi orang beragama atau menjadikan warga masyarakat dan warga negara yang baik, juga tidak untuk suatu jabatan, melainkan menjadi seorang individu yang bebas. Dja'far Siddik, Konsep Dasar Ilmu Pendidikan Islam, (Bandung: Cita Pustaka Media, 2006: 39).

Penelitian sebelumnya antara lain dari Ariyawan Agung Nugroho, S.T. 2010. Pemanfaatan E-Learnng Sebagai Salah Satu Bentuk Penerapan TI Dalam Proses Pembelajaran. Kesimpulannya adalah TI telah menawarkan media baru untuk menyebarkan informasi, yaitu media digital, dimana informasi tersusun tidak lagi atas atom-atom, tetapi dalam bit-bit, dan karenanya mempercepat penyebarannya. Lahirnya $e$ mail, e-business, e-commerce, e-cash, $e$ money, e-banking, e-government, e-learning dan sebagainya merupakan beberapa dampak penerapan TI. Terkait dengan hal tersebut, $e$ learning dewasa ini telah menjadi kebutuhan.

Berikutnya dari Harjanto Prabowo, 2007, Implementasi IT Balanced Scorecard Di Perguruan Tinggi. Dimana hasil penelitian ini menyimpulkan Penggunaan IT Balanced Scorecard diperguruan tinggi belum banyak dilakukan, namun dengan memperhatikan efiektifitas metode ini, maka perguruan tinggi perlu menata organisasi TI dan sekaligus mengevaluasi keberhasilan pengembangan sistem (aplikasi), pengembangan investasi komputer dan jaringan, kualitas produk dan jasa TIK, serta peningkatan kualitas sumberdaya manusia.

Selanjutnya melalui penelitian Diana Rahmawati dkk. 2010. Pengaruh Pemanfaatan Teknologi Informasi Terhadap Kualitas Pelayanan Pegawai Administrasi Dan Pengaruh Kualitas Pelayanan Pegawai Administrasi Terhadap Kepuasan Mahasiswa Di Lingkungan FISE UNY, disimpulkan bahwa Pemanfaatan teknologi informasi tidak berpengaruh terhadap kualitas pelayanan pegawai bagian administrasi. 


\section{Metodologi Penelitian}

\section{Model dan Sumber Data Penelitian}

Metode penelitian pada dasarnya merupakan cara ilmiah untuk mendapatkan data dengan tujuan dan kegunaan tertentu dimana cara ilmiah tersebut mengandung arti bahwa kegiatan penelitian tersebut didasarkan pada ciri-ciri keilmuan yaitu rasional, empiris dan sistematis Sugiyono (2010:9).

Penelitian ini menggunakan metode deskriptif kualitatif. (Moleong, 2008:6) menjelaskan bahwa penelitian deskriptif yaitu penelitian yang menggambarkan dan melukiskan keadaan obyek penelitian pada saat sekarang sebagaimana adanya berdasarkan fakta-fakta. Penelitian ini merupakan usaha untuk mengungkapkan masalah atau keadaan atau peristiwa sebagaimana adanya sehingga hanya bersifat sebagai pengungkap fakta. Tujuan penelitian deskriptif kualitatif dalam penelitian ini yaitu untuk memberikan gambaran secara sistematis tentang pemanfaatan dan implementasi teknologi informasi Jogiyanto (2003) dan Belson (2003) serta implementasi TI melalui perspektif Balance Scorecard (Kaplan, 2000). Data merupakan bahan yang sesuai untuk memberi jawaban terhadap masalah yang dikaji. Sumber data dalam penelitian ini menggunakan dua sumber data, yaitu data primer dan data sekunder (Afifuddin dan Saebeni, 2009: 117)

\section{Metode Pengumpulan Data}

Data diperoleh dengan melakukan observasi, survai dan dokumentasi laporan jumlah mahasiswa untuk mendapatkan informasi yang berkaitan dengan pemanfaatan TI dan perspektif Balancescorecard.

\section{Analisis Data}

Dalam melakukan kajian ini, peneliti menggunakan metode analisis deskriptif kualitatif, yaitu mencari informasi melalui buku-buku yang relevan melalui survai dan observasi terhadap mahasiswa pengguna TI dan perspektif Balancescorecard, kemudian menganalisa diinterpretasikan dalam bentuk deskripsi hasil pengukuran terhadap implementasi pemanfaatan TI sehingga tergambar hasilnya baik bagi mahasiswa, fakultas serta universitas untuk jangka panjang (Maleong:2008).

\section{Teknik Pengumpulan Data}

Teknik pengumpulan data merupakan langkah yang paling strategis dalam penelitian, karena tujuan utama dalam penelitian adalah mendapatkan data. Pada penelitian kualitatif pengumpulan data dilakukan pada kondisi yang alamiah (natural setting), sumber data primer, dan teknik pengumpulan data dengan metode observasi dan wawancara mendalam (in depth interview), dan dokumentasi (Sugiyono, 2010)

\section{Hasil dan Pembahasan Deskripsi Objek Penelitian}

Objek penelitian merupakan Mahasiswa Program Studi (PS) Si Manajemen Tahun Akademik 2014-2015 Fakultas Ekonomi Dan Ilmu Sosial (Fekonsos) Universitas Islam Negeri Sultan Syarif Kasim Riau. Fekonsos berdiri berdasarkan SK Pendirian PS bernomor 2417/D/T/2001 Wider Mandate. Tanggal SK pendirian PS yaitu 19 Juli 2001, dimana ditandatangani oleh Pejabat, Direktur Jenderal Pendidikan Tinggi Satryo Soemantrii Brodjonegoro. Penyelenggaraan PS yaitu tangal 27 Desember 1997 dengan Nomor SK Izin Operasional Dj.I/ 32 / 2011. Sedangkan tanggal SK Izin Operasional 11 Januari 2011.

Prodi S1 Manajemen memiliki jumlah mahasiswa 1420 dan terdapat tiga Konsentrasi Manajemen Keuangan, Manajemen Sumberdaya Manusia dan Pemasaran. Dibawah Kepemimpinan Ketua Prodi DR. Mulia Sosiady, SE., MM., Ak., CA. Tahun 2017 terdiri dari 28 kelas yang berada di Semester Ganjil (I, III, V dan VII). Mahasiswa yang menjadi objek penelitian ini berada pada Semester IV dimana implementasi Teknologi 
Informasi berhubungan erat dengan mata kuliah Sistem Informasi Manajemen (SIM) sebagai bukti sangat diperlukannya informasi dibidang Akademik maupun penggunaana teknologi itu sendiri dengan pemanfaatan jaringan On-line baik dalam proses belajar mengajar (PBM) serta upaya dalam penciptaan usaha melalui jiwa wirausaha (Enterpreneur)

Balanced scorecard yang dikembangkan oleh Norton dan Kaplan memberikan solusi terhadap tuntutan ini. Peran balanced scorecard dalam sistem manajemen strategis adalah: memperluas perspektif dalam setiap tahap sistem manajemen strategis, membuat fokus manajemen menjadi seimbang, mengaitkan berbagai sasaran secara koheren, dan mengukur kinerja secara kuantitatif.

Kelebihan sistem manajemen strategis berbasis balanced scorecard dibandingkan konsep manajemen yang lain adalah menunjukkan indikator outcome dan output yang jelas, indikator internal dan eksternal, indikator keuangan dan non-keuangan, dan indikator sebab dan akibat dan mendorong proses perubahan. Balanced scorecard juga diterapkan dalam situasi-situasi yang rutin, antara lain: pada saat menyusun rencana alokasi anggaran, menyusun manajemen kinerja, melakukan sosialisasi terhadap kebijakan baru, memperoleh umpan balik.

\section{Implementasi Teknologi Informasi}

Dalam penelitian ini untuk menghasilkan informasi yang tepat, akurat dan bermanfaat, peneliti memperolehnya melalui wawancara dengan perwakilan mahasiswa dari masing-masing Konsentrasi yaitu Konsentrasi Manajemen Keuangan, Manajemen Sumberdaya Manusia dan Manajemen Pemasaran. Pertama, apa sebenarnya manfaat yang dirasakan mahasiswa setelah mempelajari Teknologi Informasi dan implementasi pada Proses Pembelajaran melalui mata kuliah terkait yaitu Sistem Informasi Manajemen (SIM). Dari materi yang disampaikan terutama tentang
Sistem Informasi, dimana berhubungan dengan masing-masing departemen atau bagian yang ada didalam perusahaan yaitu Keuangan, Pemasaran, Sumberdaya, Produksi atau Manufaktur maupun Informasi dan Teknologi. Semua sudah memiliki manajemen informasi sistem sehingga berguna bagi kelangsungan dan kemudahan dalam operasionalisasi perusahaan setiap hari.

Sebagai implementasi langsung mahasiswa dan Dosen pengampu mengadakan kunjungan industri sebagai salah satu penunjang Proses Belajar Mengajar (PBM), yaitu ke PT. Indofood CBP Sukses Makmur, Tbk, Cabang Pekanbaru, guna mengamati, memahami dan mengetahui secara langsung proses produksi yang memanfaatkan Sistem Informasi Manajemen (SIM) salah satunya sub sistem Manufaktur, SDM, Keuangan dan Pemasaran. Melalui SIM mempermudah perhitungan Bahan baku dalam kebutuhan produksi Manufacturing Requirement Planing (MRP), Reorder Point (RoP), Computer Integrated Manufacturing (CIM) dan lain-lain istilah yang terkait dengan SIM.

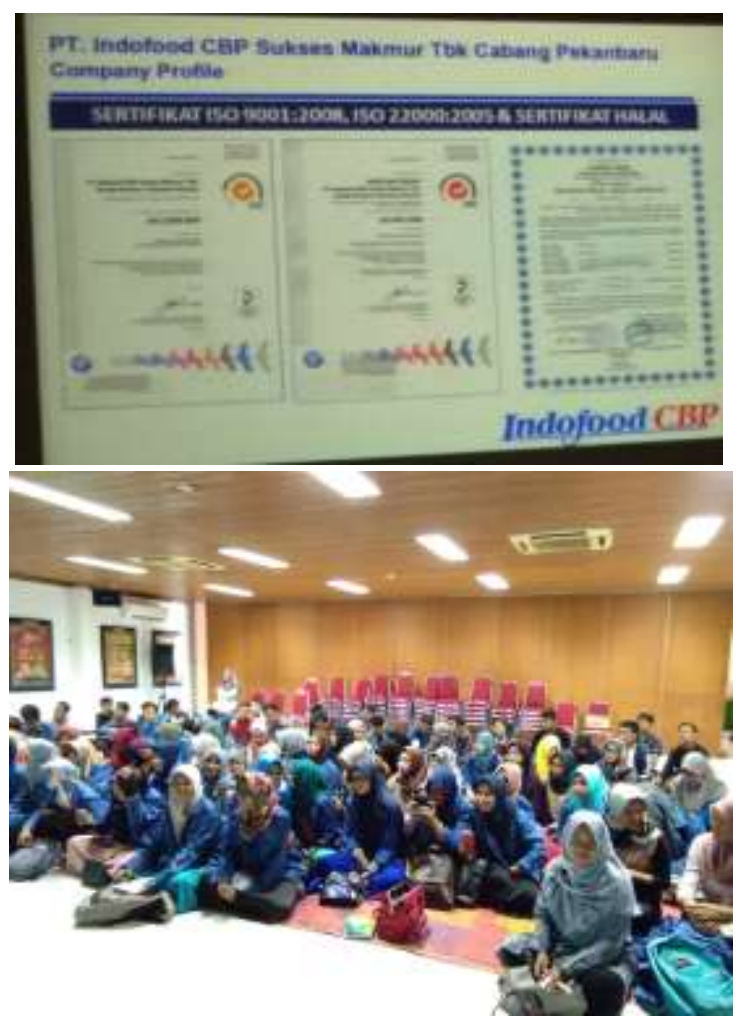



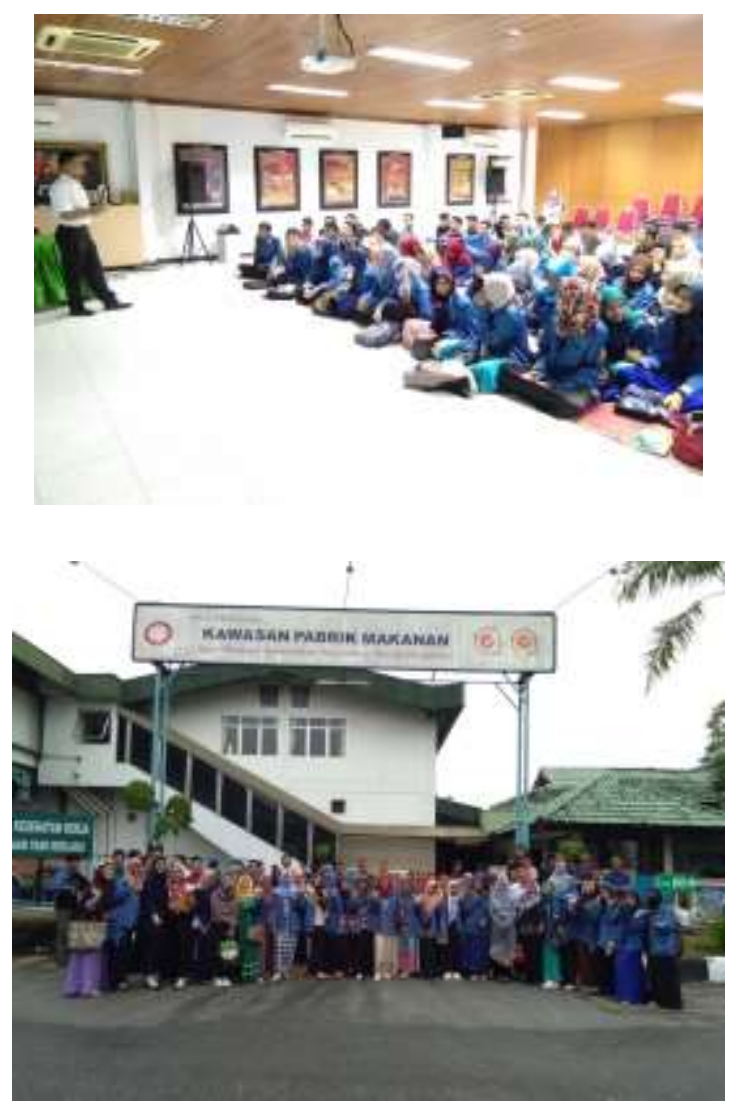

Gambar 3: Dokumentasi Kunjungan Industri Sebagai Penunjanag PBM

Begitu pula dengan pemanfaatan informasi mata kuliah yang diberikan Dosen dapat dishare di media internet melalui Blog yang sudah dibuat mahasiswa antara lain mulai dari mata kuliah sampai dengan berwirausaha (Enterpreneur)〉
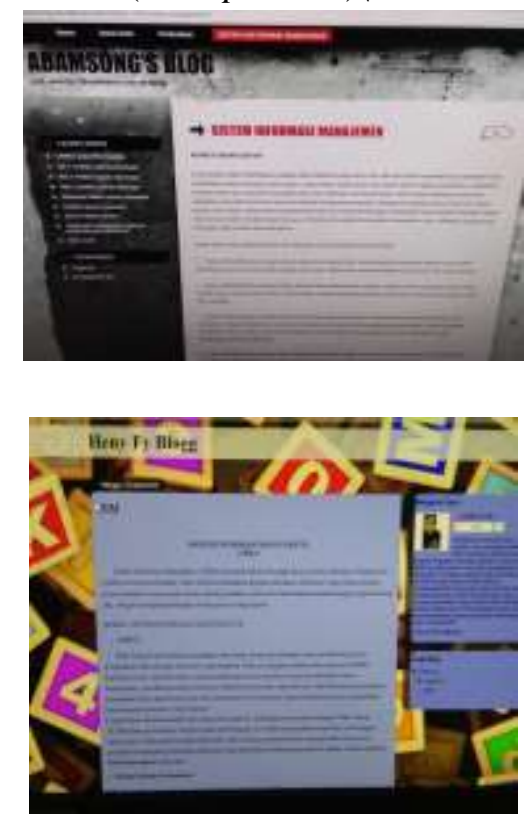

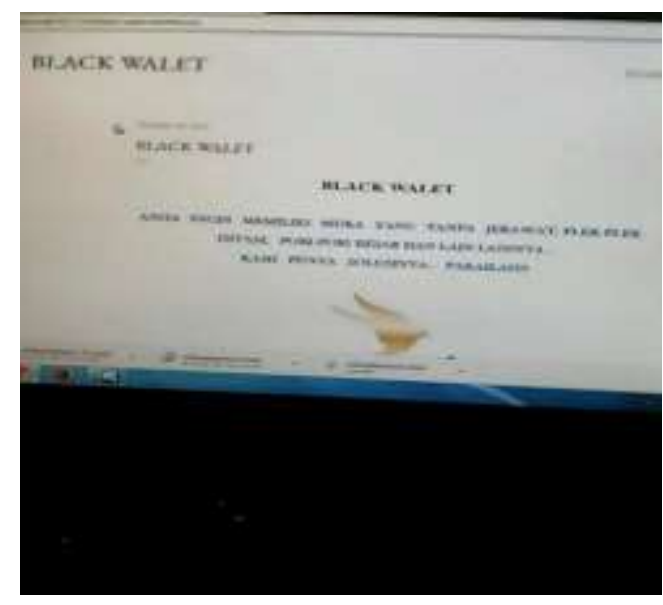

Gambar 4: Dokumentasi Pemanfaatan Implementasi TI Oleh Mahasiswa

\section{Penggunaan Balanced Scorecard}

Balanced Scorecard digunakan dalam hampir keseluruhan proses penyusunan rencana. Tahapan penyusunan rencana pada dasarnya meliputi enam kegiatan berikut: perumusan strategi, perencanaan strategis, penyusunan program, penyusunan anggaran, implmentasi dan pemantauan.

\section{a. Perumusan Strategi}

Tahap ini ditujukan untuk menghasilkan misi, visi, keyakinan dan nilai dasar, dan tujuan institusi. Proses perumusan strategi dilakukan secara bertahap, yaitu: analisis eksternal, analisis internal, penentuan jati diri, dan perumusan strategi itu sendiri. Tujuan institusi sebagaimana yang kita ketahui secara umum adalah mencerdaskan anak bangsa dengan mengintegrasikan nilai Islam.

\section{Analisis Eksternal Dan Internal}

\section{Analisis Eksternal}

Terdiri dari analisis lingkungan makro dan mikro. Analisis lingkungan makro bertujuan mengidentifiksasi peluang dan ancaman makro yang berdampak terhadap value yang dihasilkan organisasi kepada pelanggan. Analisis Eksternal Mikro diterapkan pada lingkungan yang lebih dekat dengan institusi yang bersangkutan. Dalam dunia pendidikan, lingkungan tersebut adalah industri dimana suatu perusahaan termasuk didalamnya. 
keberhasilan alumni yang memiliki keunggulan baik kemampuan dan kompetensi khusus berdasarkan masing-masing Konsentrasi di Prodi S1 Manajemen dan tetap terintegrasi Nilai Islami.

\section{Analisis Internal}

Ditujukan untuk merumuskan kekuatan dan kelemahan institusi. Kekuatan tersebut antara lain: kompetensi yang unik, sumberdaya keuangan, individu (SDM) maupun pemasar yang andal, keterampilan yang unggul, citra yang baik, keunggulan biaya, kemampuan inovasi tinggi. Sedangkan kelemahan institusi antara lain: posisi persaingan yang tinggi, terutama dari Universitas Negeri yang memang sudah memiliki citra dimata masyarakat, fasilitas yang 'usang' dalam hal ini masih dirasakan kurang supportnya jaringan IT, kesenjangan kemampuan manajerial, lini yang sempit, yakni faktor komunikasi personal.

\section{Penentuan Jati Diri}

Penentuan jati diri organisasi terdiri dari perumusan misi, visi, keyakinan dasar, nilai dasar dan tujuan institusi. Keyakinan dasar merupakan pernyataan yang selalu dipegang teguh oleh pimpinan untuk mengatasi hambatan dan ketidakpastian. Nilai dasar yang merupakan bimbingan dari pimpinan terhadap mahasiswa dalam menentukan pilihan yang akan muncul setiap saat. Sedangkan Tujuan akan dijelaskan hubungannya dengan pencapaian visi melalui empat perspektif unggulan.

\section{b. Perencanaan Strategis}

Perencanaan strategis meliputi proses penentuan sasaran, tolok ukur, target dan inisiatif. Sasaran adalah kondisi masa depan yang dituju. Sasaran bersifat komprehensif: sesuai dengan tujuan dan strategi, merumuskan sasaran secara koheren, seimbang dan saling mendukung. Beberapa pedoman dalam menentukan sasaran adalah: sasaran harus menentukan hasil yang terukur dan dicapai. Artinya institusi benar-benar mempersiapkan calon tenaga kerja siap pakai.

Target berfungsi memberikan usaha tambahan tetapi tidak bersifat melemahkan semangat, berjangka waktu dua sampai lima tahun agar memberikan banyak waktu untuk melakukan terobosan, membatasi banyak target, berfokus pada terobosan dalam satu atau dua area kunci, tergantung pada nilai (value), kesenjangan (gap), ketepatan waktu (timeliness), hasrat/keinginan (appetite), keterampilan (skill). Target dapat ditentukan dengan menggunakan hasil benchmarking. Benchmarking adalah untuk mendapat informasi praktek terbaik, untuk membangun suatu kasus yang jelas guna mengkomunikasikan betapa pentingnya mencapai target-target itu. Inisiatif adalah langkah-jangka panjang untuk mencapai tujuan dan tidak harus spesifik pada satu bagian, tetapi dapat bersifat lintas fungsi/bagian, mengindentifikasi hal-hal penting yang harus dilakukan oleh organisasi agar mencapai tujuan.

\section{c. Penyusunan Program}

Proses penyusunan program adalah menjabarkan inisal mempersiapkan dan memperkirakan program Akreditasi Unggul. Hal ini merupakan investasi yang diperlukan untuk setiap program, menghitung perkiraan penerimaan yang dapat diperoleh dan menghitung perkiraan laba/hasil yang akan diperoleh.

\section{d. Penyusunan Anggaran}

Penyusunan anggaran bertujuan untuk menentukan kegiatan tahun berikutnya dan sumber daya yang diperlukan. Anggaran disusun berdasarkan iniatif yang telah dirumuskan. Anggaran yang baik adalah: merupakan rencana tindakan terperinci, merupakan rencana satu-dua tahunan, menguraikan biaya yang diperlukan, mengidentifikasi pencapaian terpenting kegiatan tsb, siapa yang akan bertanggung jawab, sebagai referensi menyusun rencana 
kinerja individual, ditulis secara singkat namun lengkap, alat untuk memantau kinerja dan diperbarui apabila terjadi perubahanperubahan. Dengan demikian balanced scorecard mendukung suatu sistem manajemen yang lengkap dengan mengkaitkan strategi jangka panjang ke penganggaran tahunan.

\section{e. Implementasi}

Tahap ini melaksanakan kegiatan sesuai rencana. Kegiatan yang dilakukan dalam institusi diharapkan dari tahun ketahun mengalami perubahan kearah perbaikan baik itu dari sumberdaya mahasiswa maupun sarana dan prasarana pendukung dan yang terpenting adalah komitmen dari pimpinan institusi untuk mewujudkan visi, misi, tujuan maupun sasaran di tahun 2018 menuju 2023.

\section{f. Pemantauan dan Pengendalian}

Tahap ini membandingkan kinerja dengan target. Berbagai kemungkinan hasil adalah berhasil, gagal, dan variasi diantara keduanya. Prinsip umum dalam pemantauan adalah mengukur kinerja, membandingkan kinerja, melakukan tinjauan ulang, memberi penghargaan dan mengidentifikasi hasil yang dicapai, mempelajari pengalaman, menyesuaikan dan menyegarkan strategi, dan melakukan perbaikan. Pemantauan harus diikuti dengan pengendalian.

\section{Implementasi Ti Melalui Pendekatan Balancescorecard}

Perspektif keuangan, dalam hal keuangan diharapkan sekolah dapat mengelola keuangan secara baik dan maksimal. Pendapatan keuangan, dari mahasiswa dan dari pemerintah empat tahun terakhir melalui Uang Kuliah Tunggal (UKT) diharapkan dapat dikelola dengan baik bagi kepentingan institusi.

Perspektif pelanggan, pelanggan dalam hal ini adalah mahasiswa terutama Dosen membuat rumusan pembelajaran yang menarik bagi para mahasiswanya, sehingga menimbulkan ketertarikan bagi para mahasiswa dalam proses belajar mengajar (PBM). Hal ini terlihat dari indeks prestasi institusi, prestasi apa yang diperoleh oleh mahasiswa melalui keunggulan Akreditasi yang makin meningkat juga bisa dilihat dari feedback dari indikator kepuasan para orang tua.

Perspektif proses, terciptanya atmosfir yang baik dalam kegiatan belajar mengajar (PBM) merupakan tujuan dari proses. Untuk itu Dosen sebagai tenaga pendidik harus dibekali ilmu yang baik dan kompeten. Dosen dapat melakukan kegiatan pelatihan-pelatihan atau PreTeaching agar meningkatkan

kemampuan Dosen dalam mengajar terutama dari Kompetensi Pedagogik.

Perspektif pembelajaran dan pertumbuhan, seiring dengan pertumbuhan ekonomi dan informatika, dua hal yang tidak dapat dipungkiri peran pentingnya dalam pendidikan. Untuk itu Dosen, mahasiswa dan orang tua harus saling bekerjasama menghadapi perubahan lingkungan internal dan eksternal.

\section{Kesimpulan}

Dari pembahasan yang sudah dikemukakan, maka dapat diambil kesimpulan:

1. Melalui implementasi TI, mahasiswa semakin efisiensi dalam pemanfaatan TI itu sendiri baik dalam Proses Belajar Mengajar (PBM) melalui Blog maupun pemanfaatan serta proses menjadi Enterpreneur dalam E-Business.

2. Penerapan Manajemen Balance Scorecard dapat membantu proses pendidikan Balance Scorecard memuat sistem manajemen peningkatan mutu berkelanjutan dan dengan keseimbangan pengelolaan disetiap unit (Fakultas). Balance Scorecard kini menjadi tolak ukur yang yang dapat digunakan untuk meningkatkan kinerja menjadi lebih baik. 
3. Perumusan balanced scorecard bukan suatu pekerjaan sekali jadi, melainkan tugas yang terus menerus, dengan setiap saat ada proses penyempurnaan dan yang terpenting adalah ia dimanfaatkan untuk mencapai visi dan misi institusi terutama UIN Suska Riau.

\section{Saran}

1. Melalui implementasi TI diharapkan jangan sampai disalah gunakan untuk kepentingan oknum tertentu yang nantinya akan merusak Proses Belajar Mengajar (PBM) misal ada oknum yang meng-hack akun masing-masing Dosen maupun mahasiswa didalam program iRaise.

2. Diharapkan Tugas pengawasan dari pemerintah terkait di institusi pendidikan dalam hal ini pendidikan tinggi dipermudah jika instansi pemerintah memiliki strategi berbasis Balanced Scorecard.

\section{Daftar Pustaka}

Al Quran Terjemahan

Arikunto Suharsimi, 2006, Prosedur Penelitian Suatu pendekatan Praktik, PT. Rineka cipta, Jakarta.

Fathul, Wahid. 2007. Teknologi Informasi

Pendidikan. PT Ardana Media.

Yogyakarta.

Frenny. 2009. Penerapan Balanced Scorecard Sebagai Pengukuran Kinerja pada RSUD Pandan Arang Kabupaten Boyolali. Skripsi, Tidak Dipublikasikan, Fakultas Ekonomi, Universitas Sebelas Maret.

Giri, Efraim Ferdinan. Januari-April 1998. Balanced Scorecard: Suatu Sistem Pengukuran Kinerja Strategik. Kajian Bisnis, No 13, 35-46. Hongren, T Charles. 1991. "Pengantar Akuntansi Manajemen", Jakarta, Erlangga

http://sendyfrandika.ngeblogs.com/2009/10/10 /dasar-dasar-komputer-dan-komponen- komponennya. (On-line. diakses, 06 Jan 2010).

Kaplan R.S. \& Norton, D.P 2000.; The Balanced Scorecard, Translating Strategy into Action.

Mahmudi. 2007. Manajemen Kinerja Sektor Publik, UPP STIM YKPN. Yogyakarta.

Maleong. Lexy J. 2008 Metodologi Penelitian Kualitatif. PT Remaja Rosdakarya

Bandung.

Mondy. 2007. Human Resource Management $10^{\text {th }}$ Edition Strategic Human Resource Management: An Overview. Prentice Hall. New York.

Muhammad Fakhri Husein, SE dan Amin Wibowo, SE, MBA. 2000. Sistem Informasi Manajemen. UPP AMP YKPN. Yogyakarta.

Pidarta, Made, Landasan Kependidikan: Stimulus Ilmu Pendidikan Bercorak Indonesia,Cet. 2 (Jakarta: Rineka Cipta, 2007.

Richardus, Eko Indrajit. 2000. Pengantar Konsep Dasar Manajemen Sistem Informasi Dan Teknologi Informasi. Elex Media Komputindo. Jakarta.

Uno, Hamzah B. Profesi Kependidikan. Cet. 4. Jakarta: Bumi Aksara, 2009.

Wangsi, Husni, 2006. Analisis Penilaian Kinerja Dengan Pendekatan Balanced

Scorecard Pada Rumah Sakit Umum Daerah Tugurejo Semarang. Skripsi, Tidak Dipublikasikan, Fakultas Ekonomi, Universitas Diponegoro.

Wirawan, 2009, Evaluasi Kinerja Sumber Daya Manusia, Salemba Empat. Jakarta. 